\title{
THE USE OF NEW TECHNOLOGY AND RISING INEQUALITY IN NEW ZEALAND: EVIDENCE FROM UNIT RECORD DATA
}

\author{
Chris Hector ${ }^{1}$ \\ University of Waikato
}

\begin{abstract}
From the late $19^{\text {th }}$ century to the late $20^{\text {th }}$ century inequality was generally in decline in all the developed countries, including New Zealand. However this pattern was abruptly reversed in the 1970s, and at least up to the mid $1990 \mathrm{~s}$ inequality was generally on the rise again. The last quarter of the $20^{\text {th }}$ century was also marked by rapid uptake of new information and communication technologies (ICT). prompting many commentators to ask whether there might be a connection. The present study uses unit record data from the Household Labour Force Survey to explore the extent to which wage inequality is related to new technology in New Zealand, and the extent to which it is correlated with skills and qualifications. The relationship appears to be relatively strong for workers in the lower half of the distribution, suggesting that workers with low skill levels have very poor prospects in industries using new technology. If the adoption of new technology is to be further encouraged it may be important to raise the skill levels of workers near the bottom of the distribution.
\end{abstract}

\section{Introduction}

During the 1980 s and 1990 s inequality in earnings and incomes increased considerably in New Zealand as in many of the industrialized countries. This rising inequality was coincident with the rapid diffusion of Information and Communications Technologies (ICT), leading many commentators to believe that the latest phase of technological developments has been biased in favour of more-skilled workers, and that the rise in inequality reflects the associated premium for skills.

However the number of experts in computing and related fields in New Zealand has been estimated at no more than four percent of the workforce (Engelbrecht, 2001). It therefore seems implausible that the increasing inequality can be explained by the wages of ICT specialists alone.

For skill-biased technological change to be the cause of rising wage inequality, a much more general demand for higher skills throughout industries with rapid uptake of new technology would seem to be necessary. One way in which this might occur is by ICTs being indirectly responsible through their effect on workplace organisation. A large proportion of the New Zealand workforce is employed in industries which have experienced substantial reorganisation, in part following the adoption of new technologies, and it is therefore plausible that widening earnings dispersion reflects the increased returns to the knowledge and skills required to maximize the potential of the new workplace.

This paper reports the findings of an investigation into the extent to which wage inequality is related to new technology and the extent to which it is correlated with skills and qualifications. Specifically it uses unit record data collected by Statistics New Zealand in the June 2002 Income Supplement to the Household Labour Force Survey to estimate wage differentials in the entire New Zealand economy.

To explore the role of technical change I relate data on the industry use of computers from the 1996 Input-Output tables to the earnings dispersion. Quantile regression was used to estimate how the proportion of industry spending on computing affects workers at the $10^{\text {th }}$ and $90^{\text {th }}$ percentiles of the log wage distribution, and whether that log wage gap is wider in industries making more intensive use of computers. A significant association was found between greater use of computing and wider wage disparities, but this widening dispersion is fully explained by qualifications and occupations. This finding suggests that the widening dispersion reflects a mismatch of worker qualifications to industry needs, rather than any specific ICT effects.

Section 2 of this paper reviews the international and New Zealand literature on inequality and technological change. The data and methods of analysis are discussed in section 3 , and Section 4 presents the findings of the quantile regression estimates. Section 5 discusses some of the implications of these findings.

\section{Review of the Literature}

Over the 90 years from the 1880 s to the 1970 s the immense inequalities of the mid- $19^{\text {th }}$ century were steadily eroded. The all-pervasive economic growth

\footnotetext{
'Department of Economics, University of Waikato, Private Bag 3105, Hamilton. Phone: (7) 856-2889. E-mail: chector@waikato.ac.nz. The financial support of grant UOWX0016 from the Foundation for Research, Science and Technology is gratefully acknowledged. Thanks also go to Dr John
} Gibson for valuable assistance and comment. 
stemming from the spread of industrialization benefited all sectors of society, but disproportionately helped those at the bottom of the distribution. The wages of lowskilled workers rose faster than the cost of living, and the income gaps between the top and the bottom of the distribution became narrower (Aghion, Garcia-Penalosa and Caroli, 1998; Goldin and Margo, 1992).

From about 1974 this pattern of growth with a lowincome bias was abruptly reversed (Karoly, 1993; Greenwood and Yorukoglu, 1997). The growth rate slowed down sharply in almost all the more developed countries, and in many cases the spread of benefits became much less equitable. Such growth as did occur was largely captured by households in the upper deciles of the distribution (Karoly, 1993), and numerous studies in many OECD countries show a marked widening of income disparities in the last two decades. (Goldin and Margo, 1992: Acemoglu, 2001). This widening of inequality is particularly true for the United Kingdom and the United States (Freeman and Katz, 1995; Gottschalk and Smeeding, 1997), but has also been found in New Zealand (Borland, 2000; Dixon, 1998; Chatterjee, Podder and Mukhopadhaya, 2003).

In some countries, notably the United States, the lower deciles suffered a decline in absolute as well as relative terms (Juhn, Murphy and Pierce, 1993; Nickell, 1998; Slaughter, 1999). During the restructuring era of the late 1980 s and early 1990s this also appears to have been the case in New Zealand. The bottom half of the income distribution enjoyed no improvement in real household incomes in the 12 years after 1988, with the median houschold income rising 30.97 percent from $\$ 31000$ in 1988/89 (Statistics New Zealand, 1998: 168) to $\$ 40600$ (Statistics New Zealand, 2000: 145), while the CPI rose by 33 per cent from 766 to 1020 (Statistics NZ, 2002: $546)$

Rising inequality may result from changes in the distribution of earnings within groups of workers with similar characteristics or from changes between groups. The between-group changes follow from changes in the composition of the workforce and from changes in the carnings premium associated with various characteristics. Several existing studies in New Zealand look at workforce composition changes, for example due to the growth of the 'information workforce' (Engelbrecht, $2001)$, and also look at changes in between-group returns to characteristics, such as schooling (Maani, 1999).

The rising inequality of the last 25 years contains elements of both between group and within group dispersion (Aghion, Garcia-Penelosa and Caroli, 1998; Borjas, 2000), and a number of commentators have tried to establish which is the more significant. Jeff Borland concluded that within group inequality was the more significant in Australia (Borland, 1999) and probably also in New Zealand (Borland, 2000). This New Zealand finding was generally supported by Hector and Gibson (2002), who used changes in income inequality as reported in the Population Census and found declining within-group incquality for low skill workers, but substantially rising within group inequality among the higher skill workers. However, between group inequality is probably the more critical from a policy perspective, since there is some evidence that within group inequality is transitory while between group inequality is more permanent (Aghion and Howitt, 2002).

Since the end of World War II the numbers of school leavers continuing to tertiary education has been rising steadily in OECD countries (Machin, 2001) including New Zealand (Maani, 2000), and during the 1960s and 1970 s this was accompanied by a decline in the returns to education as the supply of more qualified workers outstripped demand (Juhn, 1999). The recent widening of the wage differentials at a time of increasing supply indicates that the demand for skills has been rising even faster than supply (Juhn, Murphy and Pierce, 1993; Pryor and Schaffer, 1999). Moreover, since 1980 not only has the earnings dispersion increased, the demand for the less skilled has plummeted (Berman, Bound and Machin, 1998; Levy and Murnane, 1996; Nickell and Bell, 1995).

The period when wage disparities began to widen was also a period of rapidly changing technology in the workplace, leading many commentators to believe that skill biased technological change is the prime mover. However the technological changes could be a coincidence, and a number of other reasons such as declining union power and changing industrial structures in the face of globalization have been advanced (Levy and Murnane, 1992; Borland, 2000).

During the 1990 s the trade explanation was widely seen as the most plausible alternative to the skill-biased technological explanation (Wood, 1995; Rodrik, 1997), but the advanced industrial countries trade far more with each other than they do with the less developed world, and the trade explanation has largely fallen out of favour as most commentators have concluded that the volumes of trade are too small to have generated inequality effects of the magnitude observed (Bhagwati, 1995; Krugman, 1994). Moreover the trade explanation fits particularly poorly with the New Zealand experience, where exports are largely concentrated in the less technologized primary industries, and if anything trade appears to reduce inequality (Ballingall and Lattimore, 2002).

Deunionization and other labour market changes are another possible contributory factor. However it has been estimated that the reduced union membership only explains some 15 percent of the observed rise in wage inequality (Haskel, 1999) and most authors agree that labour market institutions generate at most only a small part of the effect (Card, Kramarz and Lemieux, 1999; Simonazzi and Villa, 1999; Webster and Tseng, 2002).

Skill biased technological change, while not the proven cause, is currently the prime candidate (Bound and Johnson, 1995; Goldin and Katz, 1998). Consequently, there has been considerable discussion in the economics literature on the different types of technological change. Some technologies, especially those relating to specific industries, evolve progressively and display steady 
incremental improvements rather than more radical innovations (Freeman, 1992: 77). In contrast, "General Purpose Technologies" or GPTs (Bresnahan and Trajtenberg, 1995; David, 2000) spark a revolutionary change in modes of production, affecting countless industries. Examples of GPTs include steam power in the nineteenth century and electrification at the turn of the century (Helpman, 1998). Many authors have suggested that information and communication technologies represent the latest of these GPTs (Brynjolfsson and Hitt, 2000 ), with the general purpose nature of cheaper and better ICT facilitating co-invention of more and more complex uses (Bresnahan, 1999: F402).

Whether a new general purpose technology, such as ICT, raises or lowers the demand for skills can only be determined empirically. Either outcome is possible depending on which segment of the labour market is most affected and the nature of the impact. Consequently, the effect of new technology on wage differentials depends on whether the new technology complements skilled workers or substitutes for them. As Krueger (1993: 34) explains:

"In the former case [complementarity] the computer revolution is likely to lead to an expansion in earnings differentials and in the latter case [substitution] it is likely to lead to compression in skill-based differentials."

A link between increasing use of technology and greater returns to education is widely accepted as very plausible, since returns to schooling have been found to be higher in industries making greater use of advanced technology (Allen, 1996), and the rate of skill upgrading tending to be greatest in industries with greater computer investment (Autor, Katz and Krueger, 1998; Johnson, 1997).

However, the evidence suggests that rather than a simple complementarity between computer use and individual workers' skills, there is a complementarity between skilled workers and an automated workplace (Bresnahan, 1999; DiNardo and Pischke, 1997). A more educated workforce is more adaptable to new ways of working (Shultz, 1975; Bowles, Gintis and Osborne, 2001) and computerization appears to be strongly associated with occupational restructuring (Brynjolfsson and Hitt, 2000; Wolff 2002). Moreover, the evolving patterns of inequality have been markedly different in different countries, even between countries at a similar stage of technological development such as the United States and Canada (Murphy, Riddell and Romer, 1998). It therefore seems likely that the rising skill premium is a reflection of better educated workers enjoying a comparative advantage in the implementation of new technology (Bartel and Lichtenberg, 1987; Chun, 2003).

\section{Data and Methods}

Statistics New Zealand (SNZ) conducts a quarterly Household Labour Force Survey (HLFS), to which they add an annual Income Supplement each June. The present study uses the Income Supplement for June 2002, which contains extensive detail on the various sources of income, including income from wages, investments and welfare payments, for a cross-section of some 29000 New Zealanders aged 15 and over. In order to focus on wage effects those respondents were excluded who reported no income from earnings, or unrealistic earnings (less than $\$ 4.00$ per hour), reducing the sample size to 12 919.

Not only does the Income Survey distinguish between earnings and other forms of income, it also provides information on normal hours of work per week and earnings derived from those hours. One of the derived values provided by $\mathrm{SNZ}$ is the usual hourly wage from the primary job. This figure provides a robust basis for the analysis of industry, occupation and skill level effects on wage dispersion, since it is hourly wage rates which most accurately reflect the willingness of employers to pay for particular skills.

\section{Measures of Industry Use of Information and Communications Technologies (ICT)}

There is no generally accepted best proxy for the uptake of new technologies. Some proxies that have been used include R \& D expenditure, age of capital, use of patents, and expenditure on ICT equipment and services (Bartel and Sicherman, 1999). The present study uses industry expenditure on computers and computer services drawn from the 1996 inter-industry tables compiled by Statistics New Zealand, which are the most up to date tables available. These tables are published at two levels of detail, but the more detailed 126 industry by 210 product version was chosen because it provided separate commodity data for computer hardware, and computer software and services. Statistics New Zealand provides a concordance between their 126 industry groupings and their 49 industry groupings. Neither of these exactly matches the 62 industry division used for the HLFS data, so a new concordance between the 62 and the 126 industries was created (Concordance available on request).

Of the 58 industries there were five that had total computer and computer services purchases in excess of $\$ 100 \mathrm{~m}$ in 1996 . Wholesale and retail trade is the biggest with a total of approximately $\$ 370 \mathrm{~m}$, followed by banking, other financial services and business services, each at over $\$ 250 \mathrm{~m}$, and government administration at $\$ 180 \mathrm{~m}$. When purchases of computers and computer services are expressed relative to the size of the industry (in terms of total outlays), the sectors with the most intensive use of computers are banking, finance, insurance, business services and public administration.

At the other end of the scale the input-output tables do not record expenditure less than $\$ 1 \mathrm{M}$, and there were 11 industries with software and computer services expenditure and 25 with hardware purchases below this threshold in 1996. These are typically the primary industries, such as farming, fishing and forestry. 
Occupations, qualifications and skill levels of workers

For occupations and skill levels of workers this paper draws on the work of Nick Pappas (2001), which itself was based on the classification of occupations developed in the U.S. Department of Labor (1991) Dictionary of Occupational Titles (DOT). Pappas provides estimates of cognitive skills, interpersonal skills and motor skills for each occupation (Pappas, 2001: 213-217). The occupation classification is the Australian Standard Classification of Occupations (ASCO) revision 1, and for the present study the occupations have been grouped up to the two digit level.

The HLFS Income Supplement includes information on the highest qualification attained for each of the workers sampled. There are ten skill levels identified in the HLFS. However levels 9 and 10 together represented less than 0.6 percent of the sample, and some skill levels (eg. 5 and 8 ) are rather ill-defined, so for the purposes of the present study the groupings were compacted into five, as detailed in table 1 . The very small, totally unspecified level 10 was merged with level 6 , as that is both the most numerous class and it straddles the median.

Table 1: Qualification levels in the HLFS

\begin{tabular}{|l|l|l|l|}
\hline \multicolumn{2}{|l|}{ HES } & \multicolumn{2}{l|}{ Regrouped } \\
\hline 1 & No qualification & 1 & No qualification \\
\hline 2 & School certificate & 2 & School certificate \\
\hline 3 & Sixth form certificate & 4 & \\
\hline 4 & Higher school qualification & 4 & Higher school qualification \\
\hline 5 & Other school qualification & 4 & \\
\hline 6 & Vocational or trade qualification & 6 & Vocational or trade qualification \\
\hline 7 & Bachelor or higher degree & 7 & Bachelor or higher degree \\
\hline 8 & Other post-school qualification & 6 & \\
\hline 9 & Post-school not specified & 6 & Post-school not specified \\
\hline 10 & Not specified & 6 & \\
\hline
\end{tabular}




\section{Method of analysis}

The analysis considers both within group and between group inequality. To study within group inequality, quantile regression $(\mathrm{QR})$ was used, the $\theta$-th quantile $(0<$ $\theta<1)$ of the log wage (w) distribution for the i-th individual being specified as:

$$
\text { Quant }_{\theta}\left(w_{i} \mid x_{i}\right)=\alpha(\theta)+x_{i}{ }^{\prime} \beta(\theta)
$$

Where OLS shows deviation from the mean of a sample, QR permits estimation of the median $(\theta=0.5)$ or any other quantile. By comparing the trend in the log wage at the $10^{\text {th }}$ percentile with the trend in the log wage at the $90^{\text {th }}$ percentile it is possible to see whether wage dispersion is increasing or decreasing as an explanatory variable changes.

To investigate the extent to which the computing effect differs between groups of similar workers the various industries were flagged as high-tech or not high-tech, according to whether industry spending on computing exceeded $0.8 \%$ of total industry expenditure. This approach is similar to that of Engelbrecht and Xayavong (2004), but the cutoff was chosen to divide the worker sample into two large groups $(61 \%$ of the sample work in industries below this cutoff), rather than finding the median point of the industries themselves.

OLS regressions of log wage on the interaction of this computing intensity dummy with the five qualification level dummies were then estimated, to see whether computer intensive industries show higher returns to qualifications. These OLS regressions were also estimated controlling for characteristics such as occupation and cognitive skills. Where $\mathrm{Qi}$ is the qualification dummy and $\mathrm{HiTech}$ is the computer expenditure dummy, the specification is:

$$
\text { ln wage }=\Sigma d i Q i+\Sigma \beta i(Q i * H i T e c h)+U i
$$

\section{Findings}

Figure 1 presents quantile regression estimates for the $10^{\text {th }}$ percentile of the workforce (P10) and the $90^{\text {th }}$ percentile (P90), simply regressing log wage on age and age squared, without any controls for industry or skill effects. The Figure shows the characteristic concave curves for log wages over the working life cycle. Not surprisingly, the estimated earnings for those at the $90^{\text {th }}$ percentile are rising more steeply than for those at the $10^{\text {th }}$ percentile over most of the working age range, and the $90^{\text {th }}$ percentile curve peaks several years later. The P10 to P90 gap is widest at age 53, with a log wage gap of 1.02 representing an hourly wage difference of 2.76 times. In dollar terms, across all industries, occupations, qualification groups, and other relevant characteristics, a 53 year old person at the $10^{\text {th }}$ percentile of the wage distribution earns $\$ 9.75$ per hour, while a worker of the same age at the $90^{\text {th }}$ percentile earns $\$ 26.89$ per hour.

Figure 1 : Wage dispersion by worker age

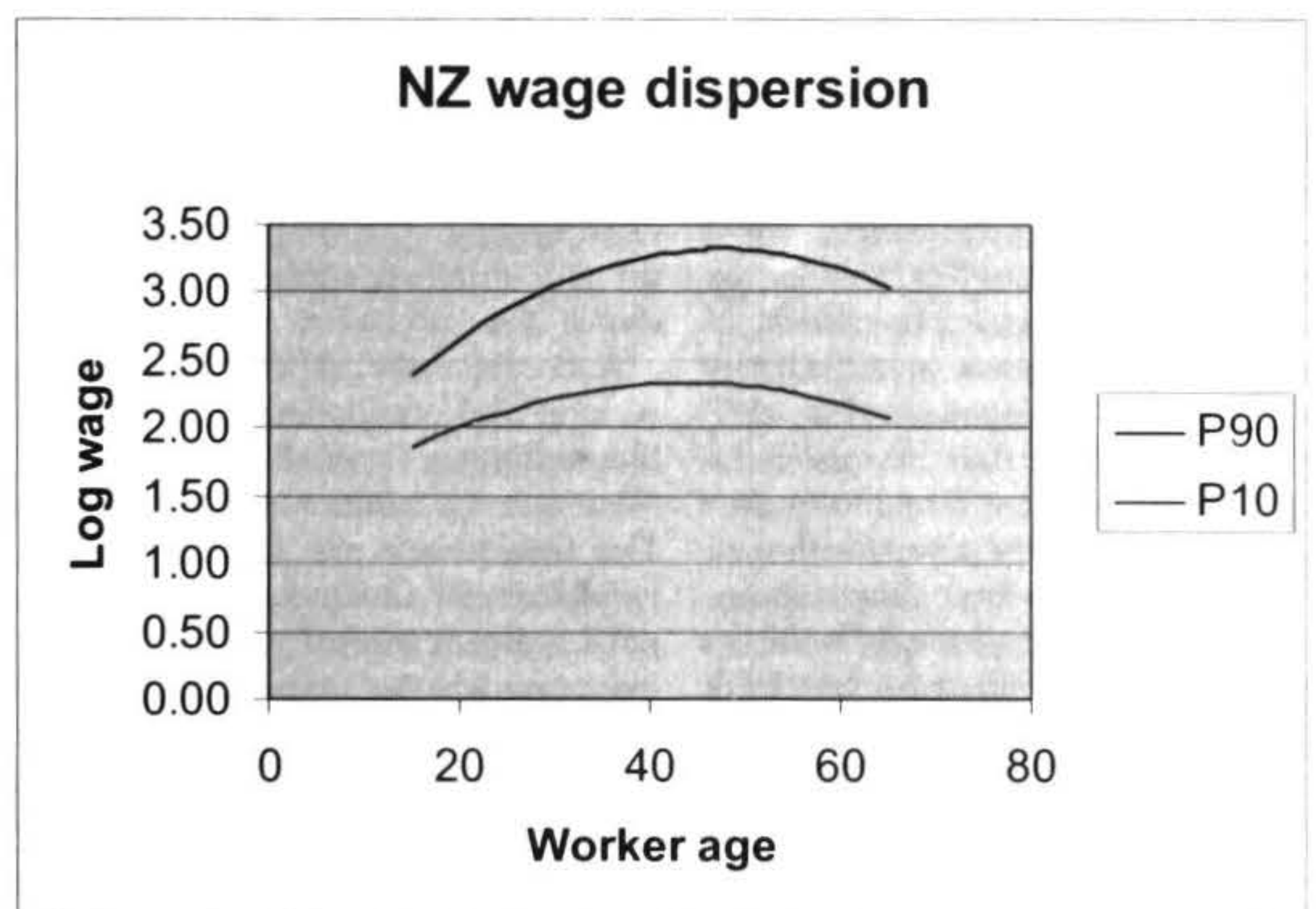

\section{Computing effects}

The dispersion was then estimated between the $10^{\text {th }}$ percentile and the $90^{\text {th }}$ percentile according to the proportion of industry expenditure on computing. The simplest specification included controls for age and age squared, because of the strong relationship between age and wages outlined above. This reveals a marked tendency for wage dispersion in New Zealand to be wider in those industries which are significant users of new technology, than it is within industries which make little use of new technology, though the $\mathrm{R}^{2}$ figure of 0.17 is too low to draw strong conclusions about the correlation (Table 2). 
Table 2: Wage dispersion by industry use of computing, controlling only for age and age squared.

\begin{tabular}{|l|l|l|l|}
\hline Variable & P10 & P90 & Difference \\
\hline Computing/total & & & \\
expenditure & 4.296 & 8.264 & 3.968 \\
\hline Age & $(9.11)^{* *}$ & $(8.99)^{* *}$ & \\
\hline & 0.05 & 0.079 & \\
\hline Age squared & $(25.06)^{* *}$ & $(19.43)^{* *}$ & \\
\hline & -0.001 & -0.001 & \\
\hline Constant & $(23.58)^{* *}$ & $(16.06)^{* *}$ & \\
\hline & 1.175 & 1.484 & \\
\hline $\mathrm{R}^{2}$ & $(30.39)^{* *}$ & $(20.54)^{* *}$ & \\
\hline Robust t-statistics in parentheses \\
* significant at 5\%; ** significant at $1 \%$
\end{tabular}

The effect of a difference of 3.968 in the coefficient on computing expenditure is to increase log wage dispersion by $0.19 \mathrm{log}$ points between those industries which have negligible computing expenditure and those which are computer intensive $(4.8 \%$ of total expenditure). This log wage difference of 0.19 represents a $21 \%$ increase in P90:P10 dispersion.

However, once the regression was re-estimated incorporating an occupation dummy, a qualification dummy and a variable representing cognitive skill, the premium attached to the computing effect disappeared. Of these three the occupation dummy was found to be the one which had the strongest explanatory power, with the coefficient on computing expenditure becoming almost the same at the $10^{\text {th }}$ percentile as it is at the $90^{\text {th }}$. This implies that the wage dispersion over industries which is correlated with computer expenditure is in fact largely explained by the occupations of the workers. When a dummy variable for qualifications is also incorporated into the equations the coefficient on computer expenditure actually becomes smaller at the $90^{\text {th }}$ percentile than it is at the $10^{\text {th }}$.

Figure 2 shows the coefficients on the industry proportion of computing expenditure at the $10^{\text {th }}$ and $90^{\text {th }}$ percentiles, for five different specifications. The first pair of bars shows the estimation when no control variables are added, while the second pair incorporates a dummy variable for occupation. The third pair incorporates a further dummy for qualifications and the fourth pair is the third with the addition of a variable for cognitive skills. The fifth pair is the fourth with the incorporation of variables for marital status, sex, ethnicity, local government region of residence, and a dummy variable indicating whether or not the respondent was a migrant to New Zealand. The error bars indicate one standard error plus or minus. 
Figure 2: P10 and P90 comparisons of the computing effect, with and without the inclusion of other control variables.

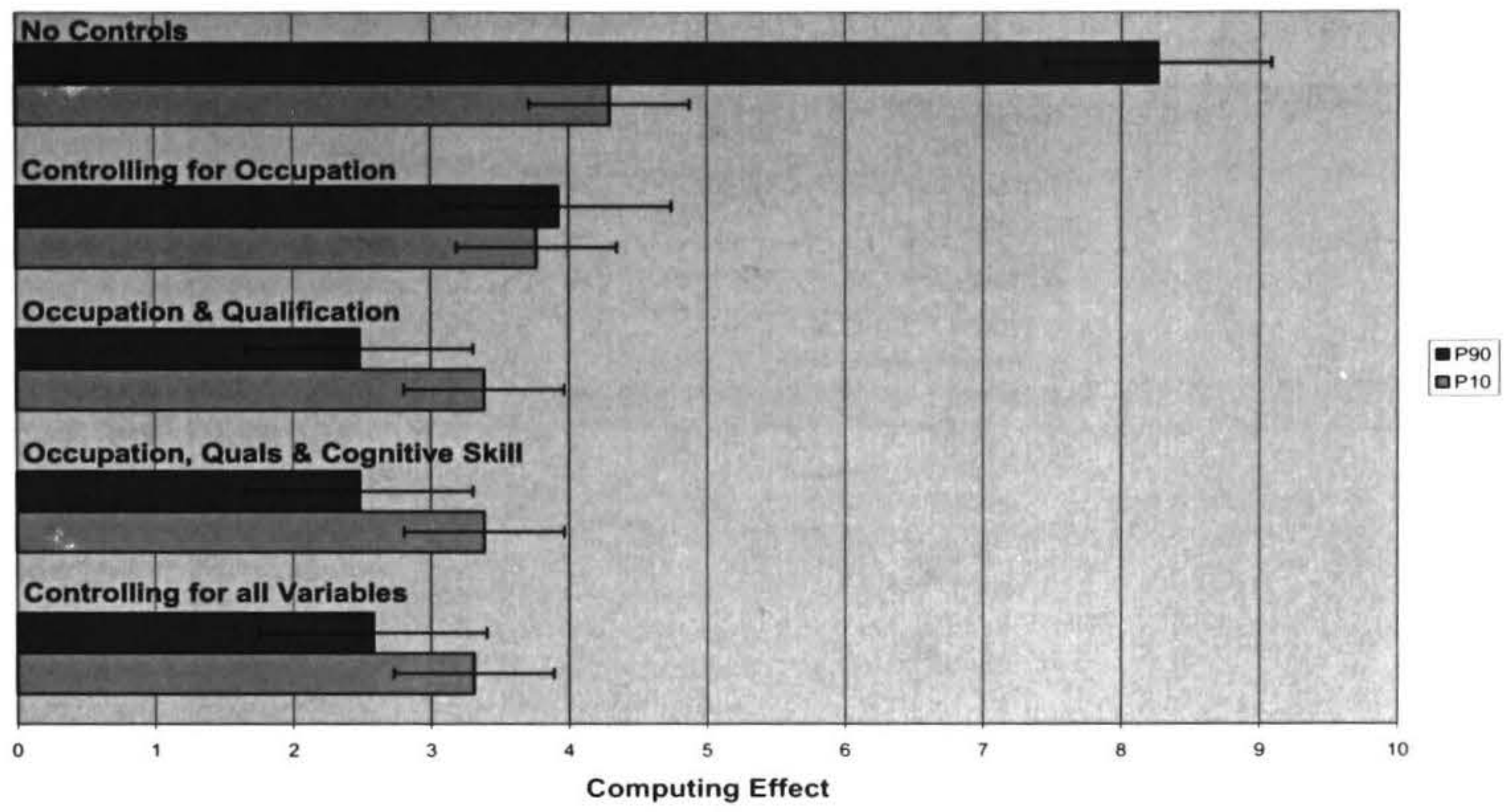

Controlling for occupation and qualifications reveals exactly the same pattern whether or not the control for cognitive skill is also incorporated (specifications 3 and 4 in Figure 2). Additional controls were brought into the model for interpersonal skills and motor skills as calculated by Pappas (2001), but the coefficients on computer expenditure remained the same as they were in the simpler specification. The coefficients on interpersonal skills and motor skills are negligible, while the small positive coefficients on cognitive skills are offset by smaller positive coefficients on the dummies for qualifications and occupation.

A number of additional control variables were introduced into the model, for worker characteristics which could possibly have significance: sex, ethnicity, marital status, migrants status and local government region of residence (specification 5 in Figure 2), but the coefficients on computing expenditure change very little. There is a slight reduction of the computing effect for the $10^{\text {th }}$ percentile workers and a slight increase in the computing effect for the $90^{\text {th }}$ percentile workers, but the relationship with wage dispersion remains almost totally explained by qualifications and occupation.
An earlier study using Population Census data (Hector and Gibson, 2002) found a tendency for the computer intensity of industries to be associated with higher withingroup inequality for workers with higher qualifications. To check whether this effect was confirmed by unit record data, the sample was divided into five groups by level of qualification, and quantile regressions were estimated at the $10^{\text {th }}$ and $90^{\text {th }}$ percentiles for each qualification level in turn.

In the simplest specification, controlling only for age and age squared, QR estimates show a substantial increase in wage dispersion associated with computer intensity, for those workers with no qualifications or only school certificate. However, for those workers who have higher schooling or vocational or university qualifications computer intensity is associated with compression of the wage differential. The same pattern is apparent when cognitive skill is also controlled for, but the coefficients on computing are somewhat muted (Figure 3. Error bars show one standard error plus or minus). For workers who have not completed university study but who have a vocational qualification the computing effect is smaller, but again shows a narrowing of the P10:P90 gap. 
Figure 3: The effect of computing intensity on within-group inequality, by highest qualification achieved, controlling for cognitive skill.

Effect of computing on log wage

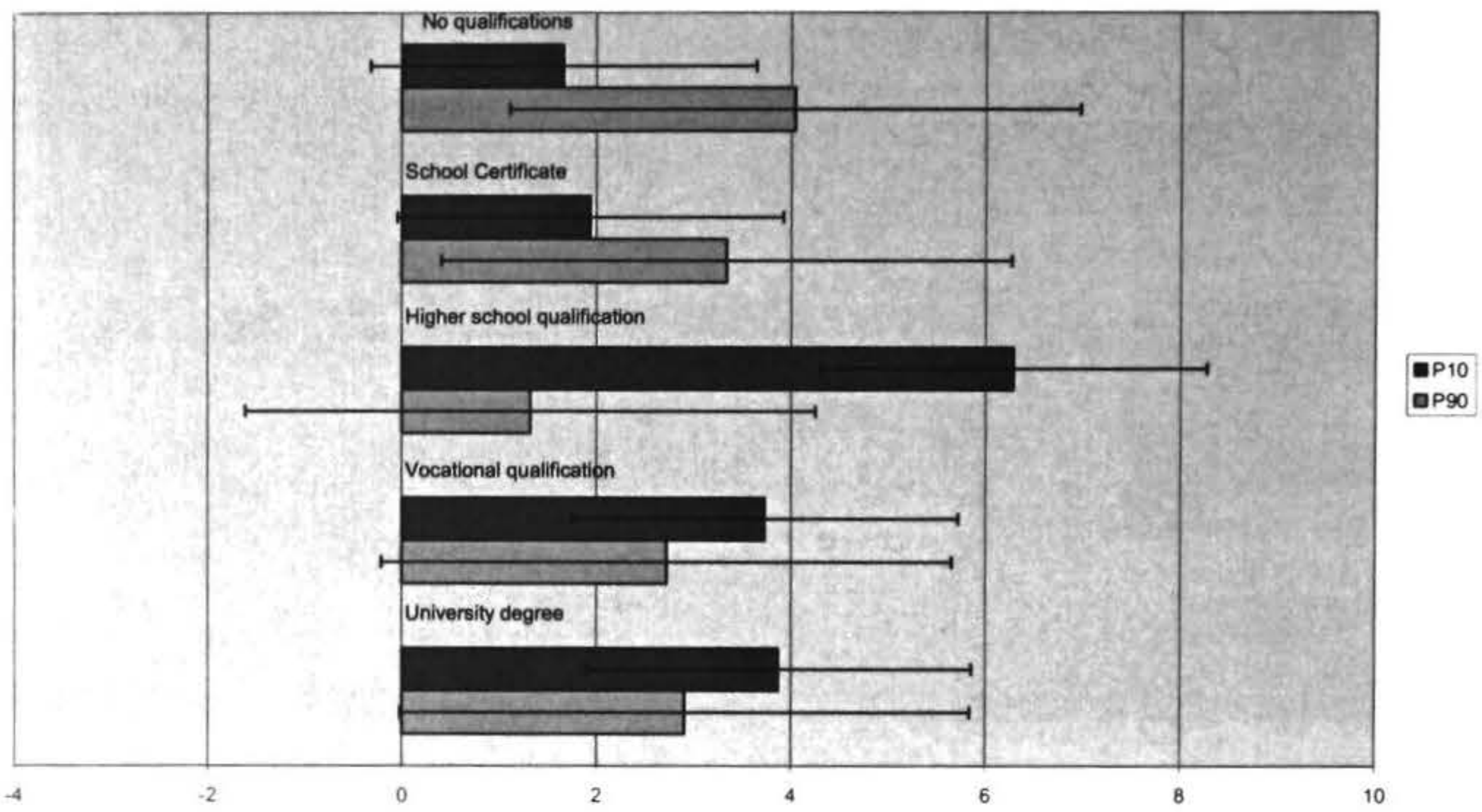

\section{Between group inequality}

Finally, in order to examine changes in between-group inequality, industries were divided into two groups according to whether their expenditure on new technology exceeds $0.8 \%$ of total industry expenditure. OLS regressions on the interaction of qualifications and technology were estimated, to see whether the return to qualifications was greater in the more computer intensive industries.

These regressions were run separately for male and female workers. For male workers the higher technology industries were associated with greater returns to qualifications at all qualification levels, with the effect most marked at the middle levels. For example, a male worker with School Certificate gains a premium of $6.78 \%$ over a male worker with no qualifications, but if they also work in a high technology industry that premium is enhanced by a further $8.34 \%$. This difference is statisticially significant $(\mathrm{t}=2.42)$.

The other male and female wage premia associated with work in high technology industries are shown in Table 3. For female workers the pattern was similar to the male pattern up to the middle levels, but for university graduates the relationship was reversed, with high technology industries associated with a lower return to qualifications.

The regressions were re-estimated including a control for cognitive skills, and the patterns were found to be similar to the uncontrolled specification. However for male degree holders the wage premium was greater, and for female degree holders the reduction in wage premium was halved. 
Table 3: Effect of higher technology uptake on returns to education at different qualification levels.

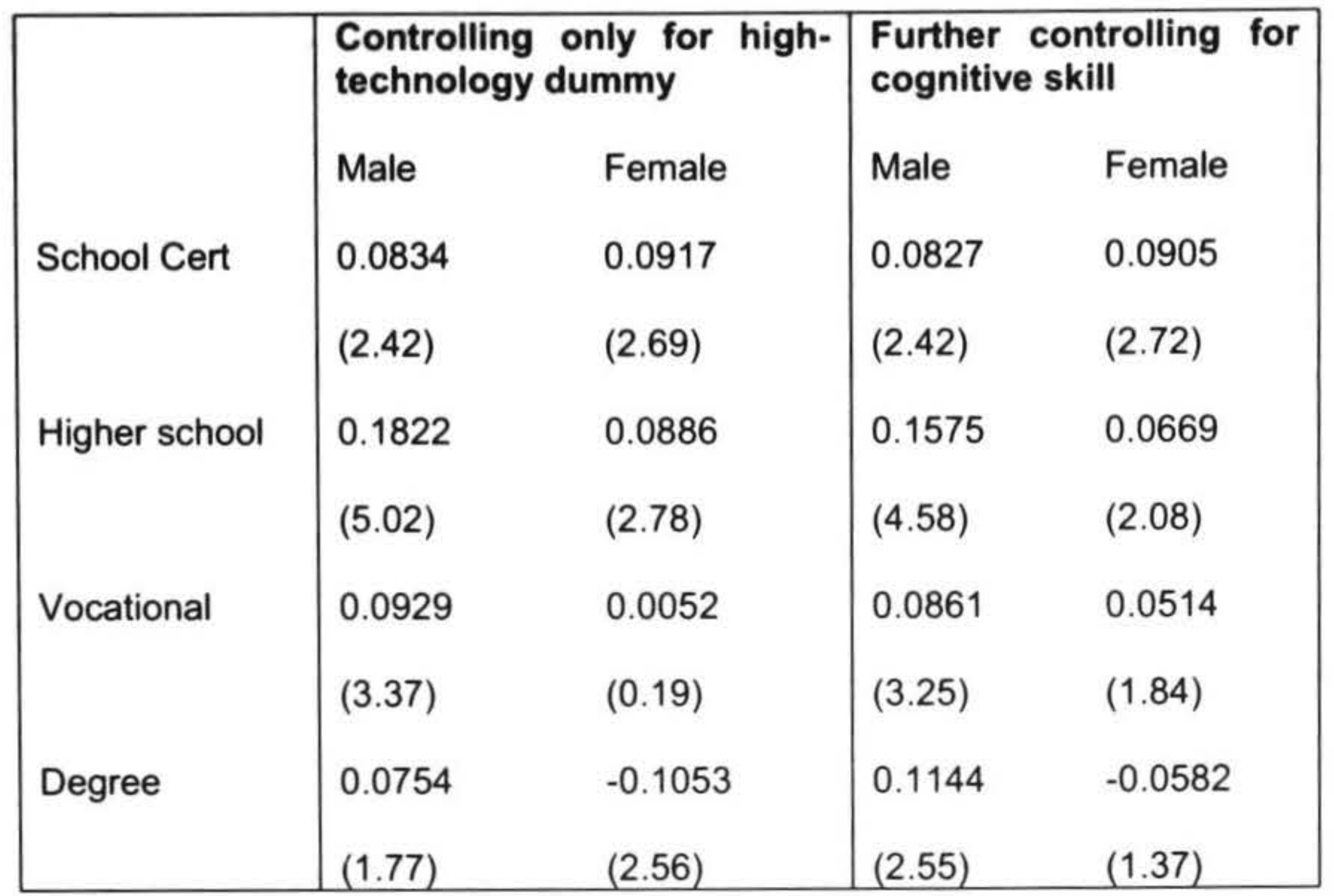

\section{Summary and Implications}

In New Zealand, the more computer intensive industries show significantly greater wage dispersion than industries which make little use of new technology, a pattern which has also been found in other countries (Allen, 2001; Katz, 2000). The high technology industries in New Zealand are associated with an increase of 0.19 in the log wage gap between the $10^{\text {th }}$ percentile and the $90^{\text {th }}$ percentile, representing an hourly wage premium of $21 \%$.

However the relationship between wage dispersion and industry use of new technology is fully explained when controls for education and occupation are introduced into the equations. Evidently it is not so much the industry use of technology as such that is driving the wage premium, as the industry need for a better educated and more appropriately qualified workforce.

There is considerable within group compression at the higher educational levels. But for those workers with no qualifications beyond School Certificate the use of technology is associated with a marked widening of the P10:P90 wage gap, tending to confirm the intuitively plausible idea that workers with few qualifications enjoy little demand in technology intensive industries.

Testing whether computer intensive industries show higher returns to qualifications also revealed a softening of the technology effect at the top of the qualification range. For male workers there was a higher return to education at all levels, but for female workers this was only true in the mid range, and for women university graduates high technology industries are associated with wage compression.
If New Zealand is to lift productivity through greater use of new technology it will probably be necessary to raise the level of education, especially of those sections of society most at risk of missing out. The returns to skill are correlated with those industries which are major users of new technology, implying that the general level of education in New Zealand is likely to be a constraint on the speed at which new technology can be further expanded.

The gaps between the bottom and the middle of the qualification range now appear to be more significant than between the middle and the top, with the workers who have no qualifications beyond School Certificate being the most disadvantaged. This in turn implies that an increased commitment to public education could be expected to have beneficial outcomes if it were aimed at raising the standards of the least educated.

If inequality is exacerbated by changing labour demand rewarding the well-positioned, there is a serious risk of self perpetuating polarisation. In addition, if within group inequality is temporary but between group inequality is more permanent (Aghion and Howitt, 2002), there would seem to be a strong case for an increased public commitment to lifting the workers at the bottom of the qualification range. In the long run it may well prove less expensive to put greater effort now into the preparation of a more appropriately educated workforce, one in which more workers can take advantage of the opportunities presented by more technologized industries, than to cope later with the consequences of a significant minority excluded through a lack of the skills which are needed to succeed in a changed environment. 


\section{References}

Acemoglu, D. (2001). Human Capital Policies and the Distribution of Income : A Framework for Analysis and Literature Review (No. Treasury working paper, 01/03). Wellington: The Treasury.

Acemoglu, D. (2002). Technical change, inequality and the labor market. Journal of Economic Literature, $40(1), 7-72$.

Aghion, P., Garcia-Penalosa, C., \& Caroli, E. (1998). Inequality and economic growth. In P. Aghion \& J. G. Williamson (Eds.), Growth, Inequality and Globalization : Theory, History and Policy (pp. 5102). Cambridge: Cambridge University Press.

Aghion, P., \& Howitt, P. (2002). Wage inequality and the new economy. Oxford Review of Economic Policy, 18(3), 306-323.

Allen, S. G. (1996). Technology and the wage structure (No. NBER working paper, 5534). Cambridge, MA: National Bureau of Economic Research.

Autor, D. H., Katz, L. F., \& Krueger, A. B. (1998). Computing inequality: Have computers changed the labor market? Quarterly Journal of Economics, $113(4), 1169-1213$

Ballingall, J., \& Lattimore, R. (2002). Trade policy and education: a factor content analysis using inputoutput tables. Paper presented at the New Zealand Association of Economists Conference, Wellington.

Bartel, A. P., \& Lichtenberg, F. R. (1987). The comparative advantage of educated workers in implementing new technology. Review of Economics and Statistics, 69(1), 1-11.

Berman, E., Bound, J., \& Machin, S. (1998). Implications of skill-biased technological change: International evidence. Quarterly Journal of Economics, 113(1245-1279).

Bhagwati, J. (1995). Trade and wages: choosing among alternative explanations. Economic Policy Review, $1(1), 42-47$.

Borjas, G. J. (2000). Labor Economics (2nd ed.). New York: McGraw Hill.

Borland, J. (1999). Earnings inequality in Australia: Changes, causes and consequences. Economic Record, 75(229), 177-202.

Borland, J. (2000). Economic Explanations of Earnings Distribution Trends in the International Literature and Application to New Zealand (No. Treasury working paper, 00/16). Wellington: The Treaury.
Borland, J., Gregory, R. G., \& Sheehan, P. J. (2001). Work Rich, Work Poor : Inequality and Economic Change in Australia. Melbourne: Centre for Strategic Economic Studies, University of Victoria.

Bound, J., \& Johnson, G. (1995). What are the causes of rising wage inequality in the United States? Economic Policy Review, 1(1), 9-17.

Bowles, S., Gintis, H., \& Osborne, M. (2001b). The determinants of earnings: a behavioral approach. Journal of Economic Literature, 39, 1137-1176.

Bresnahan, T. F. (1999). Computerisation and wage dispersion: An analytical reinterpretation. Economic Journal, 109(456), F390-F415.

Bresnahan, T. F., Brynjolfsson, E., \& Hitt, L. M. (1999). Information Technology, Workplace Organization and the Demand for Skilled Labor : Firm Level Evidence (No. NBER working paper, W7136). Cambridge, MA: National Bureau of Economic Research.

Bresnahan, T. F., \& Trajtenberg, M. (1995). General purpose technologies: 'Engines of Growth'? Journal of Econometrics, 65, 83-108.

Brynjolfsson, E., \& Hitt, L. M. (2000). Beyond computation: information technology, organizational transformation and business performance. Journal of Economic Perspectives, 14(4), 23-48.

Card, D., Kramarz, F., \& Lemieux, T. (1999). Changes in the relative structure of wages and empolyment: a comparison of the United States, Canada, and France. Canadian Journal of Economics, 32(4), 843-877.

Chatterjee, S., Podder, N., \& Mukhopadhaya, P. (2003). Equity, efficiency and social welfare: An application of generalized Lorenz dominance to New Zealand incomes data, 1984-1998. In Y. Amiel \& J. A. Bishop (Eds.), Inequality, Welfare and Poverty: Theory and Measurement (pp. 265287). Amsterdam: JAI.

Chun, H. (2003). Information technology and the demand for educated workers: disentangling the impacts of adoption versus use. Review of Economics and Statistics, 85(1), 1-8.

David, P. A. (2000). Understanding digital technology's evolution and the path of measured productivity growth: present and future in the mirror of the past. In E. Brynjolfsson \& B. Kahin (Eds.), Understanding the Digital Economy : Data, Tools and Research (pp. 49-95). Cambridge, MA: MIT Press. 
DiNardo, J., \& Pischke, J.-S. (1997). The returns to computer use revisited: Have pencils changed the wage structure too? Quarterly Journal of Economics, 112(1), 291-303.

Dixon, S. (1998). Growth in the dispersion of earnings: 1984-97. Labour Market Bulletin, 1998(1\&2), 71107.

Engelbrecht, H.-J. (2001). Gender and the information work force: New Zealand evidence and issues. Prometheus, 19(2), 135-145.

Engelbrecht, H-J. and Xayavong, V. (2004). Information and communication technology and New Zealand's productivity malaise: An industrylevel study. Palmerston North: Massey University. Department of Applied and International Economics. Discussion paper, 04-05.

Freeman, C. (1992). The Economics of Hope : Essays on Technical Change, Economic Growth and the Environment. London: Pinter.

Freeman, R. B., \& Katz, L. F. (1995). Differences and Changes in Wage Structures. Chicago: University of Chicago Press.

Goldin, C., \& Katz, L. F. (1996). Technology, skill and the wage structure: Insights from the past. American Economic Review, 86(2), 252-257.

Goldin, C., \& Katz, L. F. (1998). The origins of technology-skill complementarity. The Quarterly Journal of Economics, 113, 693-732.

Goldin, C., \& Margo, R. A. (1992). The great compression: The wage structure in the United States at mid-century. Quarterly Journal of Economics, 107(1), 1-34.

Gottschalk, P., \& Smeeding, T. M. (1997). Crossnational comparisons of earnings and income inequality. Journal of Economic Literature, 35(2), 633-687.

Greenwood, J., \& Yorukoglu, M. (1997). 1974. Carnegie-Rochester Conference Series on Public Policy, 46, 49-95.

Haskel, J. (1999). Small firms, contracting-out, computers and wage inequality: Evidence from UK manufacturing. Economica, 66(261), 1-21.

Hector, C., \& Gibson, J. (2002). Skills Differentials and Use of New Technology in New Zealand: Patterns Across Industries. Paper presented at the New Zealand Association of Economists Conference, Wellington.

Helpman, E. (1998). General Purpose Technologies and Economic Growth. Cambridge, MA: MIT Press.
Johnson, G. E. (1997). Changes in earnings inequality: The role of demand shifts. Journal of Economic Perspectives, 11(2), 41-54.

Juhn, C., Murphy, K. M., \& Pierce, B. (1993). Wage inequality and the rise in returns to skill. Journal of Political Economy, 101, 410-422.

Karoly, L. A. (1993). The trend in inequality among families, individuals, and workers in the United States: A twenty-five year perspective. In S. Danziger \& P. Gottschalk (Eds.), Uneven Tides : Rising Inequality in America (pp. 19-97). New York: Russell Sage Foundation.

Katz, L. F., \& Murphy, K. M. (1992). Changes in relative wages, 1963-1987: Supply and demand factors. Quarterly Journal of Economics, 107, 3578.

Koenker, R., \& Hallock, K. F. (2000). Quantile regression. Journal of Economic Perspectives, 15(4), 143-156.

Krueger, A. B. (1993). How computers have changed the wage structure: Evidence from microdata, 1984 1989. Quarterly Journal of Economics, 108, 33-60.

Krugman, P. (1994). Past and prospective causes of high unemployment. Paper presented at the Reducing Unemployment Symposium, Jackson Hole, WY.

Lang, K. (1998). The effect of trade liberalization on wages and employment: the case of New Zealand. Journal of Labor Economics, 16(4), 792-814.

Maani, S. (1999). Private and Public Returns to Investments in Secondary and Higher Education in New Zealand Over Time: 1981-1996 (No. Treasury working paper, 99/2). Wellington: The Treasury.

Maani, S. A. (2000). School Leaving, Labour Market and Tertiary Education Choices of Young Adults : An Economic Analysis Utilising the 1977-1995 Christchurch Health and Development Surveys (No. Working paper 00-03). Wellington: The Treasury.

Machin, S. (2001). The changing nature of labour demand in the new economy and skill-biased technology change. Oxford Bulletin of Economics and Statistics, 63(Special issue), 753-776.

Murphy, K. M., Riddell, W. C., \& Romer, P. M. (1998). Wages, skills and technology in the United States and Canada. In E. Helpman (Ed.), General Purpose Technologies and Economic Growth (pp. 283-309). Cambridge, MA: MIT Press. 
Nickell, S. (1998). The collapse in demand for the unskilled: what can be done? In R. B. Freeman \& P. Gottschalk (Eds.), Generating Jobs : How to Increase Demand for Less-skilled Workers (pp. 297-319). New York: Russell Sage Foundation.

Nickell, S., \& Bell, B. (1995). The collapse in demand for the unskilled and unemployment across the OECD. Oxford Review of Economics and Politics, 11(1), 40-62.

Pappas, N. (2001b). Earnings, inequality and skill. In J. Borland (Ed.), Work Rich, Work Poor : Inequality and Economic Change in Australia (pp. 196-218). Melbourne: Centre for Strategic Economic Studies, University of Victoria.

Pryor, F. L., \& Schaffer, D. L. (1999). Who's Not Working and Why : Employment, Cognitive Skills, Wages, and the Changing U.S. Labor Market. Cambridge: Cambridge University Press.

Rodrik, D. (1997). Has Globalization Gone Too Far? Washington, DC: Institute for International Economics.

Saunders, P., \& Taylor, R. (2002). The Price of Prosperity : The Economic and Social Costs of Unemployment. Sydney, NSW: University of NSW Press.
Schultz, T. W. (1975). The value of the ability to deal with disequilibria. Journal of Economic Literature, 13(3), 827-846.

Simonazzi, A., \& Villa, P. (1999). Flexibility and growth. International Review of Applied Economics, 13(3), 281-311.

Statistics New Zealand. (2002). New Zealand Official Yearbook, 2002. Wellington: Statistics New Zealand.

Webster, E., \& Tseng, Y.-P. (2002). The determinants of relative wage change in Australia. Australian Economic Review, 35(1), 70-84.

Wolff, E. N. (2002a). Computerization and structural change. Review of Income and Wealth, 48(1), 5975 .

Wood, A. (1995). How trade hurt unskilled workers. Journal of Economic Perspectives, 9(3), 57-80. 